\title{
Effects on food-type soybean cultivars when biofortified with different rates of zinc
}

\section{Biofortificação com doses de zinco em cultivares de soja tipo-alimentação}

\author{
Natália Trajano de Oliveira ${ }^{1 *}$, Pedro Milanez de Rezende ${ }^{1}$, Adriano Teodoro Bruzi ${ }^{1}$ \\ and Cirano Cruz Melville ${ }^{2}$
}

${ }^{1}$ Universidade Federal de Lavras, Dpto. de Agricultura, Campus Universitário, CEP: 37200-000, Lavras, MG, Brazil

2 Universidade Estadual Paulista Júlio de Mesquita Filho, Campus Jaboticabal, CEP:14884-900, Jaboticabal, SP, Brazil

( ${ }^{*}$-mail: nataliatrajanodeoliveira@gmail.com)

http://dx.doi.org/10.19084/RCA17151

Received/recebido: 2017.06.23

Received in revised form/recebido em versão revista: 2018.02.27

Accepted/aceite: 2018.03.14

\begin{abstract}
A B S T R A C T
The objective of this research was to verify the effect of biofortifying food-type soybean grains with different foliar applied zinc rates. The experiment was completely randomized with four replicates, in a $5 \times 5$ factorial scheme, which consisted of five soybean varieties: BRS 010 (black tegument), BRS 213 (yellow), BRSMG 790A (yellow), BRSMG 800A (brown), and Favorita $\mathrm{RR}^{\circledR}$ (yellow) combined with five zinc foliar rates applied at the reproductive 4 (R4) stage (0, 0.91, 1.82, 2.73, and $6.37 \mathrm{mg} \mathrm{L}^{-1}$ ). The analyzed parameters were plant height, first pod insertion height, number of pods per plant, number of grains per plant, pod weight per plant, grains mass per plant, 100-grain dry matter, mineral composition of the grains, lipid and protein content. Foliar fertilization with zinc increased plant height, grain mass, and protein content in soybean grains. It also significantly increased zinc content in the grain and this increase was independent of the studied variety, but was a function of the zinc rate applied.
\end{abstract}

Keywords: fertilization, foliar application, micronutrients, mineral composition.

\section{R E S U M O}

O objetivo desta pesquisa foi verificar o efeito da biofortificação de cultivares de soja tipo-alimentação pela aplicação de doses de zinco via foliar. O experimento foi instalado em delineamento inteiramente casualizado com quatro repetições, em esquema fatorial $5 \times 5$, consistindo em cinco cultivares de soja: BRS 010 (tegumento preto), BRS 213 (amarelo), BRSMG 790A (amarelo), BRSMG 800A (marrom) e Favorita RR ${ }^{\circledR}$ (amarelo) combinado com cinco doses de zinco aplicadas no estádio reprodutivo 4 (0, 0,91, 1,82, 2,73 e 6,37 $\left.\mathrm{mg} \mathrm{L}^{-1}\right)$. Os parâmetros analisados foram a altura da planta, altura da inserção do primeiro legume, número de legumes por planta, número de grãos por planta, massa de legumes por planta, massa de grãos por planta, massa de cem grãos, composição mineral, lipídios e proteínas dos grãos. A adubação foliar com doses de zinco aumentou a altura da planta, a massa e o teor de proteína nos grãos de soja. O uso de doses de zinco via foliar proporcionam aumento significativo do teor de zinco no grão independente da cultivar estudada, apresentando respostas crescentes no conteúdo de zinco em função da dose de zinco aplicada.

Palavras-chave: adubação, aplicação foliar, composição mineral, micronutriente.

\section{INTRODUCTION}

Micronutrient deficiencies are common in humans. Approximately one third of the world's population (2 billion people) suffers from vitamin deficiencies, particularly A and $C$, and mineral deficiencies, such as zinc ( $\mathrm{Zn})$, iron (Fe), and iodine (I) (FAO, 2015).
Zinc deficiency in the edible parts of crops, e.g., the grains, is partly due to its unavailability, which may be caused by a high soil $\mathrm{pH}$, concentrations of other ions, moisture, fertilizer addition, and other conditions that prevail in most areas (Alloway, 2009). Another factor that contributes to $\mathrm{Zn}$ unavailability is the plant inability to move 
$\mathrm{Zn}$ absorbed from the roots to the grains (Sharma et al., 2013).

Agronomic biofortification through the use of agricultural practices, such as the application of fertilizers containing $\mathrm{Zn}$, promoting the enrichment of food crops, should be a public health strategy in countries with high incidences of nutrient deficiencies (Joy et al., 2015).

Another alternative is based on plant breeding and genetic biofortification. This approach is a sustainable and cost-effective solution because it uses traditional methods, such as genotype selection for better nutritional value or genetic engineering. Both strategies can increase the mineral concentration in the edible parts of a plant and improve crop yields in low fertility soils (White and Broadley, 2009). Over the long term, agronomic biofortification is a complementary approach to breeding strategies and it is probably necessary for the success of the breeding program (Cakmak, 2008).

Soybean [Glycine max (L.) Merrill] is an important source of protein and provides large amounts of nutrients (Keatinge et al., 2011). It has a high nutritional content compared to other important crops, provides high quality protein, and contains all the amino acids necessary for the growth and maintenance of organisms (Gandhi, 2009). Currently, soybean breeding programs have been searching for productive varieties that have good agronomic characteristics and are capable of expressing their nutritional quality. These are food-type cultivars that can be used for human consumption.

Agronomic biofortification studies aimed at increasing Zn, Se, and I contents through soil fertilization have shown that soybean can accumulate between 57 and $59 \mathrm{mg} \mathrm{kg}^{-1} \mathrm{Zn}$ in the grains, which is higher than the content found in wheat (15 to $16 \mathrm{mg} \mathrm{kg}^{-1}$ ), potato (13 to $15 \mathrm{mg} \mathrm{kg}^{-1}$ ), canola (28 to $36 \mathrm{mg} \mathrm{kg}^{-1}$ ), and cabbage (20 to $61 \mathrm{mg} \mathrm{kg}^{-1}$ ) under the same experimental conditions (Mao et al., 2014). This highlights the importance of the crop as a source of nutrients in diets and the use in biofortification programs.

Foliar applications of $\mathrm{Zn}$ are an effective way of improving the $\mathrm{Zn}$ concentration in cereals. Applying a $0.5 \%(\mathrm{w} / \mathrm{v}) \mathrm{Zn}$ foliar fertilizer at more advanced growing stages of the crop instead of during the early stages provides a larger $\mathrm{Zn}$ increase in the edible parts, such as grains, which indicates that this technique can maximize Zn accumulation (Cakmak et al., 2010).

There needs to be a greater understanding of nutrient supply control during the development of improved cultivar grains that may respond favorably in adverse environments. This improved knowledge would help avoid excessive nutrient use or even toxic effects to the plants. Therefore, the objective of this research was to verify the effects of biofortifying food-type soybean varieties with different rates of foliar applied Zn.

\section{MATERIALS AND METHODS}

The experiment was carried out in a greenhouse between November 2014 and March 2015 at the Crop Science Department of the Federal University of Lavras, Minas Gerais, Brazil, located at $21^{\circ} 14^{\prime} \mathrm{S}$ latitude, $45^{\circ} 00^{\prime} \mathrm{W}$ longitude, and at an altitude of $918 \mathrm{~m}$. Plastic pots, with a capacity of $7 \mathrm{dm}^{3}$, were filled with $20 \mathrm{~cm}$ depth of medium-textured Red Latosol, whose chemical analysis results were: $\mathrm{pH}$ in water: 5.6, $\mathrm{K}: 14 \mathrm{mg} \mathrm{dm}^{-3}, \mathrm{P}$ (Mehlich-1): $0.56 \mathrm{mg} \mathrm{dm}^{-3}$, S: 9,48 $\mathrm{mg} \mathrm{dm}^{-3}$, Ca: 0.1 cmolc dm$^{-3}$, Mg: 0.10 cmolc $\mathrm{dm}^{-3}, \mathrm{Al}: 0$ cmolc $\mathrm{dm}^{-3}$, potential

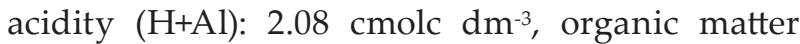

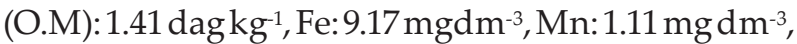
Cu: $0.76 \mathrm{mg} \mathrm{dm}^{-3}, \mathrm{~B}: 0.15 \mathrm{mg} \mathrm{dm}^{-3}$, and $\mathrm{Zn}$ : $0.26 \mathrm{mg} \mathrm{dm}^{-3}$. The total $\mathrm{Zn}$ content found in this soil is classified in the low content range for soybean.

Based on the chemical analysis, the soil was corrected to increase the base saturation by $70 \%$ using dolomitic limestone (PRNT 80.41\%). After a 30-day incubation period at $60 \%$ humidity, the plants were fertilized with $200 \mathrm{mg}$ of $\mathrm{P} \mathrm{dm}^{-3}$ and $50 \mathrm{mg}$ of S dm${ }^{-3}\left(\left(\mathrm{H}_{3} \mathrm{PO}_{4}\right) \cdot 2 \mathrm{H}_{2} \mathrm{O}+\mathrm{CaSO}_{4} \cdot 2 \mathrm{H}_{2} \mathrm{O}\right)$, and $150 \mathrm{mg}$ of $\mathrm{K} \mathrm{dm}^{-3}$ divided into two applications $(\mathrm{KCl})$. Micronutrient fertilizers were also applied. The rates were $7 \mathrm{mg} \mathrm{dm}^{-3} \mathrm{Mn}\left(\mathrm{MnCl}_{2} \cdot 4 \mathrm{H}_{2} \mathrm{O}\right)$; $3 \mathrm{mg} \mathrm{dm}^{-3} \mathrm{Cu}\left(\mathrm{CuSO}_{4} \cdot 5 \mathrm{H}_{2} \mathrm{O}\right) ; 0.5 \mathrm{mg} \mathrm{dm}^{-3} \mathrm{~B}_{(}\left(\mathrm{H}_{3} \mathrm{BO}_{3}\right)$; and $0.2 \mathrm{mg} \mathrm{Mo} \mathrm{dm}{ }^{-3}$ soil $\left.\left(\mathrm{NH}_{4}\right)_{6} \mathrm{Mo}_{7} \mathrm{O}_{24} \cdot 4 \mathrm{H}_{2} \mathrm{O}\right)$.

The experiment was a completely randomized design with four replicates in a $5 \times 5$ factorial scheme that included five soybean cultivars: BRS 
010 (black tegument), BRS 213 (yellow), BRSMG 790A (yellow), BRSMG 800A (brown), and Favorita $\mathrm{RR}^{\circledR}$ (yellow) combined with five zinc foliar rates applied at the R4 growth stage $(0,0.91,1.82,2.73$, and $\left.6.37 \mathrm{mg} \mathrm{L}^{-1}\right)$. Most of the soybean cultivars chosen are grown for human consumption (foodtype) as they have different composition and taste characteristics than the non-food types. Only the BRS Favorita $R R^{\circledast}$ variety, which is an industrial use type, is not recommended for food consumption.

Five soybean seeds were planted per pot. After the first trifoliate leaf appeared, the plants were thinned to two plants per pot. Irrigation was controlled by microaspersion, which maintained the field capacity at $60 \%$ humidity.

The foliar $\mathrm{Zn}$ fertilizer used was $\mathrm{ZnSO}_{4} \cdot 7 \mathrm{H}_{2} \mathrm{O}$. Before application, the amount of solution needed to completely wet the plant without any liquid draining into the soil was simulated. Fertilizers were applied to individual pots using a manual pre-pressure sprayer.

Pests and diseases were controlled using the insecticide Teflubenzurom at $0.05 \mathrm{~L}$ of commercial product ha ${ }^{-1}$, applied at 35 days after emergence. A fungicide, Azoxystrobin + Ciproconazole at a rate of $0.3 \mathrm{~L}$ of commercial product ha- ${ }^{-1}$ plus an additional $0.5 \%$ of the Nimbus ${ }^{\circledR}$ adjuvant, was also applied at 50 days after emergence. Weed control was performed manually.

Data collection began when the plants reached the R6 reproductive development stage (full grain). Plant height and first pod insertion height were measured with a millimeter ruler. The plants were then allowed to grow to the R8 reproductive stage (full maturation), and the yield components were measured. These were the number of pods per plant, number of grains per plant, pod weight per plant, grains mass per plant and 100-grain dry matter (mean moisture of $13 \%$ ), which were all manually counted. The mineral composition, and lipid and protein contents of the grains were determined after the grain were oven dried with forced air circulation at $65^{\circ} \mathrm{C}$ until they reached a constant mass. Then they were milled in a knife mill. The mineral composition was determined by Inductively Coupled Plasma Mass Spectrometry (ICP-MS, model iCAP 600, Thermo Scientific,
Cambridge, United Kingdom) using $100 \mathrm{mg}$ of finely ground grains, pre-digested in $4 \mathrm{~mL}$ of $\mathrm{HNO}_{3} / \mathrm{HClO}_{4}(60 / 40 \%$, v/v) according to Lyi et al. (2005). The lipid and protein contents of the grains were determined according to AOAC (2006).The $\mathrm{Zn}$ concentration increment values and efficiency were measured at the 0 and $6.37 \mathrm{mg} \mathrm{L}^{-1} \mathrm{Zn}$ application rates. They were estimated using the following formulas: Increment $\left(\mathrm{mg} \mathrm{kg}^{-1}\right)=\mathrm{Zn}$ rate variation at $6.37 \mathrm{mg} \mathrm{L}^{-1}-\mathrm{Zn}$ rate variation at $0 \mathrm{mg} \mathrm{L}^{-1}$; Efficiency $(\%)=\left\{\left[\left(\mathrm{Zn}\right.\right.\right.$ uptake at $\left.6.37 \mathrm{mg} \mathrm{L}^{-1} \times 100\right) /(\mathrm{Zn}$ uptake at $\left.\left.\left.0 \mathrm{mg} \mathrm{L}^{-1}\right)\right]-100\right\}$.

The treatment effects were determined by analysis of variance (ANOVA) and regression models using SISVAR software. The model for each parameter was selected using the significance of the coefficients and the $\mathrm{R}^{2}$ values. The means for each cultivar were compared by the Scott-Knott test (P $<0.005)$.

\section{RESULTS AND DISCUSSION}

The analysis of variance showed that variety had a significant effect on plant height, first pod insertion height, the yield components, and mineral composition. The plant height, grain mass, and lipid and protein contents were significantly affected by the $\mathrm{Zn}$ fertilization rate. The interaction between $\mathrm{Zn}$ fertilization rates and soybean variety was only significant for the zinc content in the grain.

The BRS Favorita RR ${ }^{\circledR}$ and BRSMG 800A varieties had the highest height and first pod insertion means at approximately $62 \mathrm{~cm}$ and insertion above $12 \mathrm{~cm}$, respectively (Table 1). The BRS 010 and BRS 213 varieties had the lowest plant heights (49.55 and $50.39 \mathrm{~cm}$, respectively) and first pod insertion heights (9.85 and $9.56 \mathrm{~cm}$, respectively). The ideal plant height is between 60 and $110 \mathrm{~cm}$ with a first pod insertion equal to or greater than $10 \mathrm{~cm}$. This facilitates mechanical harvesting in commercial crops and avoids bedding. The results showed that the BRS 010 and BRS 213 varieties were not in the desirable range when grown under the experimental conditions used in this study.

The BRS Favorita $R^{\circledR}$ variety had approximately 38 pods per plant, which was statistically different from the other varieties. It also had a larger 
number of grains per plant (83.48 grains). The BRS 213 variety had the lowest number of pods and grains, with means of 27.69 and 55.59, respectively.

The BRSMG 800A variety had the greatest average number of pods $(20.25 \mathrm{~g})$. It was significantly different from the BRS 010 and BRS 213 varieties, which had the lowest average number of pods (14.36 and $13.80 \mathrm{~g}$, respectively) (Table 1). However, BRS Favorita RR ${ }^{\circledR}$, BRSMG 800A, and BRSMG 790A were not significantly different, with averages of $12.21,12.19$, and $11.19 \mathrm{~g}$, respectively. There were statistical differences between this group and the BRS 010 (9.86 g) and BRS 213 (9.35 g) varieties.

Table 1 - Average results of the plant height $(\mathrm{PH})$, first pod insertion height (FPI), number of pods per plant (NPP), number of grains per plant (NGP), pods weight per plant (PWP), grains mass per plant (GMP) and 100-grain dry matter (100DM) of food-type soybean cultivars. Lavras - MG, Brazil, 2014/2015

\begin{tabular}{|c|c|c|c|c|c|c|c|}
\hline & $\mathrm{PH}$ & FPI & NPP & NGP & PWP & GMP & $100 \mathrm{DM}$ \\
\hline & \multicolumn{2}{|c|}{---------cm-------- } & \multicolumn{2}{|c|}{--------un------. } & \multicolumn{3}{|c|}{-----------'g----------- } \\
\hline BRS 010 & $49.55 \mathrm{c}^{1}$ & $9.85 \mathrm{c}$ & $33.91 \mathrm{~b}$ & $72.61 \mathrm{~b}$ & $14.36 \mathrm{c}$ & $9.86 \mathrm{~b}$ & $13.71 \mathrm{~d}$ \\
\hline BRS 213 & $50.39 \mathrm{c}$ & $9.56 \mathrm{c}$ & $27.69 \mathrm{c}$ & $55.59 \mathrm{c}$ & $13.80 \mathrm{c}$ & $9.35 \mathrm{~b}$ & $17.47 \mathrm{~b}$ \\
\hline BRSMG 790A & $54.72 \mathrm{~b}$ & $12.01 \mathrm{~b}$ & $33.89 \mathrm{~b}$ & $68.83 \mathrm{~b}$ & $16.99 \mathrm{~b}$ & $11.29 \mathrm{a}$ & $17.19 \mathrm{~b}$ \\
\hline BRSMG 800A & $62.22 \mathrm{a}$ & $14.06 \mathrm{a}$ & $35.85 \mathrm{~b}$ & $69.64 \mathrm{~b}$ & $20.25 \mathrm{a}$ & $12.19 \mathrm{a}$ & $18.96 \mathrm{a}$ \\
\hline BRS Favorita RR & $62.02 \mathrm{a}$ & $12.37 \mathrm{~b}$ & $38.14 \mathrm{a}$ & $83.48 \mathrm{a}$ & $17.89 \mathrm{~b}$ & $12.21 \mathrm{a}$ & $15.76 \mathrm{c}$ \\
\hline $\mathrm{CV}(\%)$ & 5.51 & 15.58 & 13.33 & 14.89 & 13.7 & 12.95 & 7.61 \\
\hline
\end{tabular}

${ }^{1}$ Means followed by the same lower case letter in the columns are from the same group according to Scott-Knott test $(\mathrm{p} \leq 0.05)$.

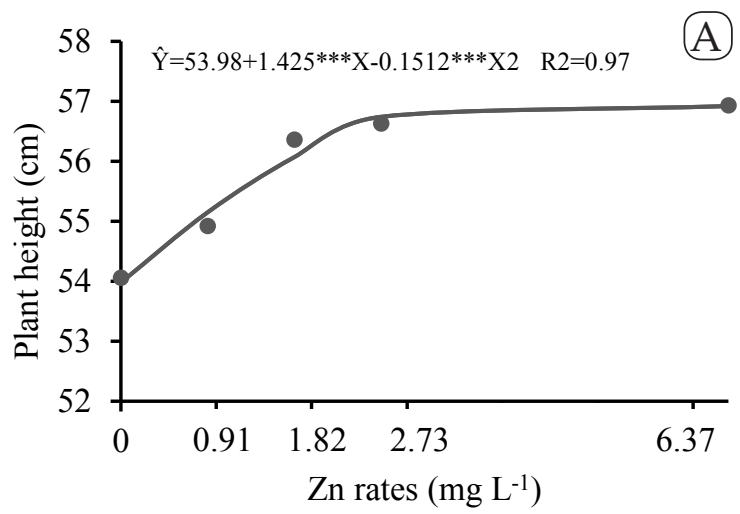

The 100-grain dry matter is an important characteristic for human consumption varieties (Table 1). The BRSMG 800A variety had the highest average 100-grain dry matter (18.96 g), followed by varieties BRS 213 and BRSMG 790A (17.47 and $17.19 \mathrm{~g}$, respectively). Variety BRS 010 had the lowest 100-grain dry matter (13.71 g).

The height of the plants was also significantly affected when the $\mathrm{Zn}$ application rates increased (Figure 1A). The $2.73 \mathrm{mgL}^{-1}$ rateproduced the greatest increases in plant height compared to $0 \mathrm{mg} \mathrm{L}^{-1}$. Increasing the $\mathrm{Zn}$ rates also had the same effect on the grain mass per plant (Figure 1B). Again, the $2.73 \mathrm{mg} \mathrm{L}^{-1}$ application rate produced the greatest increase in grain mass per plant. Although foliar $\mathrm{Zn}$ application is usually carried out at the R4 stage, a reproductive development stage, plant heights tend to become stable at the R6 (fully filled vegetable) stage. It is during this stage that the plant reaches its maximum mass accumulation of pods and achieves its highest dry mass and nutrients in the plant and grains (Bonato, 2000).

The lipid content in the dry grains was greatest in variety BRS 010 cultivar $(20.10 \%)$, which was significantly different from the other varieties (Figure 2A). The effect of $\mathrm{Zn}$ application rate on lipid content in the grain was described by a linear model. The lipid content decreased when the $\mathrm{Zn}$ rate increased. The protein content was best described by a quadratic model (Figure 2B). The highest $\mathrm{Zn}$ content was approximately $45 \%$ when $2.73 \mathrm{mg} \mathrm{L}^{-1} \mathrm{Zn}$ was applied.

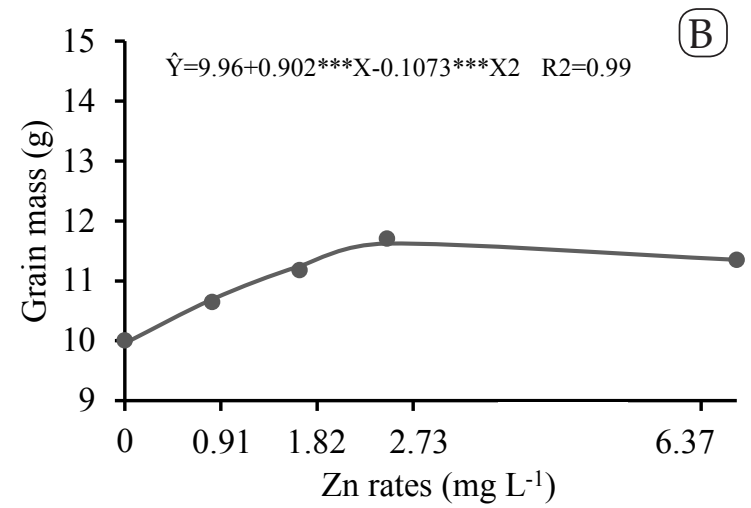

Figure 1 - Plant height (A) and grain mass per plant (B) of food-type soybean cultivars when biofortified with different rates of zinc. ${ }^{* * *}$ : significant at and $0.1 \%$ probability by the F-test. 

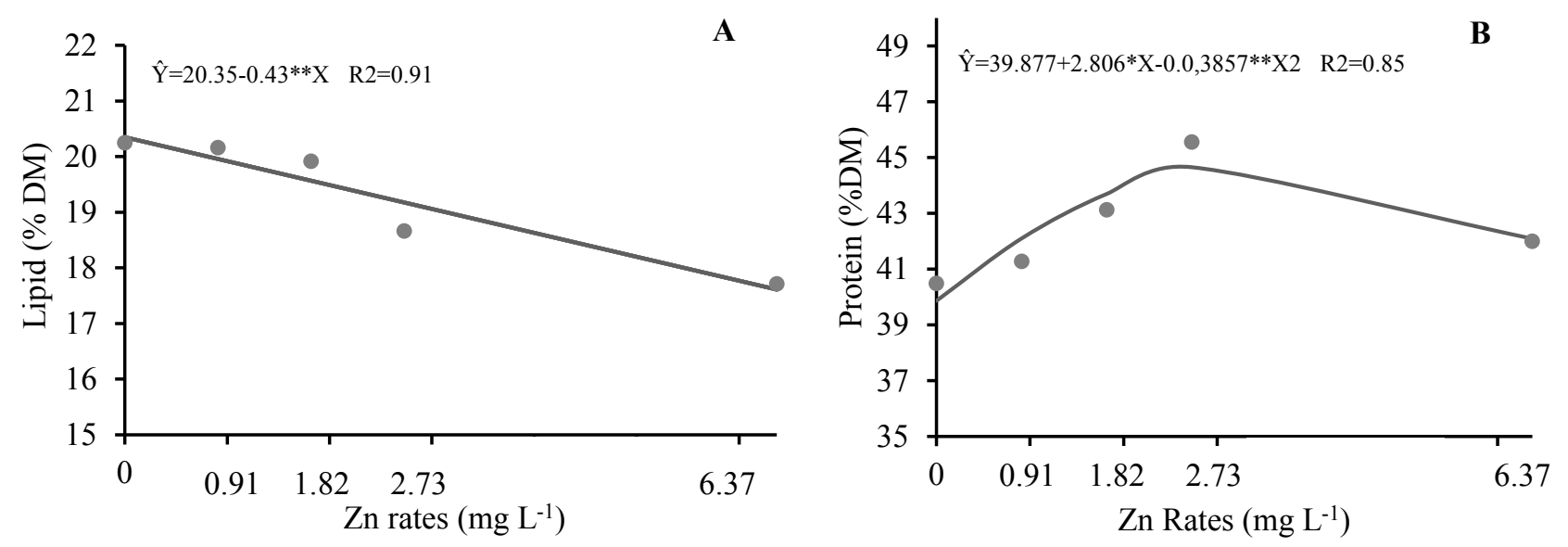

Figure 2 - Lipid (A) and protein (B) content in of food-type soybean cultivars when biofortified with different rates of zinc. ** and $* * *$ : significant at 1 and $0.1 \%$ probability by the F-test.

Previous studies carried out with soybean grains recommended for human consumption reported that the grains contained 16 to $22 \%$ lipids and 23 to $43 \%$ protein (Gonçalves et al., 2014; Ciabotti et al., 2016).

Zinc is an essential element and is involved in several plant growth and metabolism processes, including protein synthesis and lipid metabolism. The correlation between protein and oil content is negative because an increase in protein content is correlated with a reduction in oil content and vice versa (Moraes et al., 2006).

The grain zinc content was positively affected by the $\mathrm{Zn}$ application rate. Foliar $\mathrm{Zn}$ applications significantly increased the $\mathrm{Zn}$ content in the soybean grains (Figure 3). Variety BRSMG 790A had the highest grain $\mathrm{Zn}$ content $\left(64 \mathrm{mg} \mathrm{g}^{-1}\right)$ when $\mathrm{Zn}$ was applied at $6.37 \mathrm{mg} \mathrm{L}^{-1}$, which was $80 \%$ more than the content found in the control treatment $\left(0 \mathrm{mg} \mathrm{L}^{-1}\right)$.

Foliar applications of $\mathrm{Zn}$ produces better results in some crops than in others. Zhao et al. (2011) found that a $\mathrm{Zn}$ foliar application did not increase the $\mathrm{Zn}$ grain concentration in wheat plants if the plant could absorb sufficient $\mathrm{Zn}$ through the soil solution. However, foliar $\mathrm{Zn}$ application $(0.5 \%$ zinc sulfate) increases rice grain $\mathrm{Zn}$ concentration, especially when it was applied after flowering because it produced the best agronomic and nutritional benefits (Boonchuay et al., 2013).

The $\mathrm{Zn}$ contents recorded in this study were superior to the reported averages, indicating that $\mathrm{Zn}$ accumulation in the grains was high when Zn was applied foliarly. Previous studies on the $Z n$ contents in soybean grains suggested that the $\mathrm{Zn}$ contents in the grains were between 22 and $45 \mathrm{mg} \mathrm{kg}^{-1}$ (Esteves et al., 2010; Rigo et al., 2015; Brunini et al., 2016).

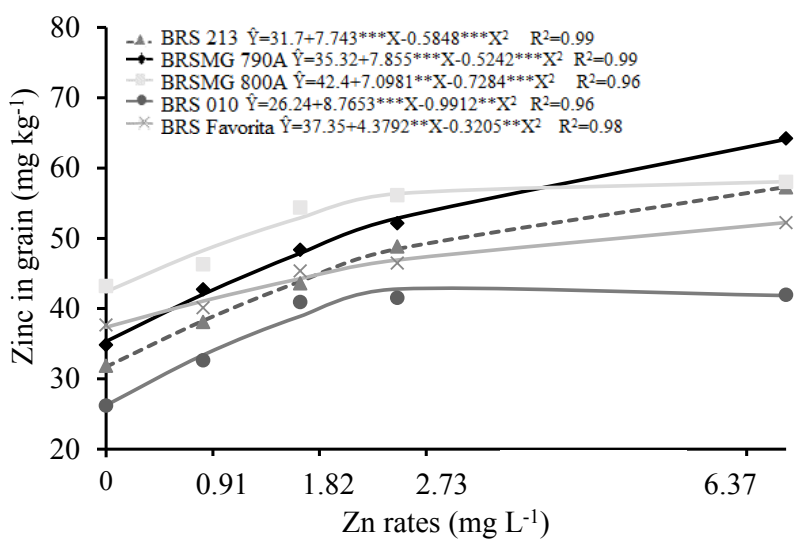

Figure 3-Zinc content in grains of food-type soybean cultivars when biofortified with different rates of zinc. ** and ${ }^{* *}$ : significant at 1 and $0.1 \%$ probability by the F-test. 
Zinc applications led to 39.87 to $81.44 \%$ Zn uptake efficiency in the grains. The efficiency increased by approximately $29 \mathrm{mg} \mathrm{kg}^{-1}$ in the $6.37 \mathrm{mg} \mathrm{L}^{-1}$ treatment compared to the $0 \mathrm{mg} \mathrm{L}^{-1}$ treatment (Table 2). Variety BRSMG 790A produced the highest increase in grain $\mathrm{Zn}$ content, which was $28.77 \mathrm{mg} \mathrm{kg}^{-1}$ higher when $6.37 \mathrm{mg} \mathrm{L}^{-1} \mathrm{Zn}$ was applied compared to the control. Furthermore, uptake efficiency was $81.44 \%$. The BRS Favorita RR ${ }^{\circledR}$ variety had the smallest increment $\left(14.89 \mathrm{mg} \mathrm{kg}^{-1}\right)$ with an uptake efficiency of $39.87 \%$. The BRS 010 variety had the lowest $\mathrm{Zn}$ content compared to the other varieties. These results show the difference between genetic material and the capacity for $\mathrm{Zn}$ accumulation in the grain.

Table 2 - Estimated values of zinc concentration increment and efficiency using the fertilization rates 0 and $6.37 \mathrm{mg} \mathrm{L}^{-1}$ of zinc, in food-type soybean cultivars. Lavras - MG, Brazil, 2014/2015

\begin{tabular}{lllll}
\hline & \multicolumn{4}{c}{ Zn rates $\left(\mathrm{mg} \mathrm{L}^{-1}\right)$} \\
\cline { 2 - 5 } Cultivar & 0 & 6,37 & $\mathrm{INC}^{1 /}$ & $\mathrm{EF}^{2 /}$ \\
\hline BRS 010 & 26.24 & $42.78^{*}$ & 16.54 & 59.51 \\
BRS 213 & 31.70 & 57.29 & 25.59 & 80.74 \\
BRSMG 790A & 35.32 & 64.09 & 28.77 & 81.44 \\
BRSMG 800A & 42.40 & 58.06 & 15.66 & 36.93 \\
BRS Favorita RR ${ }^{\circledR}$ & 37.35 & 52.24 & 14.89 & 39.87 \\
\hline
\end{tabular}

${ }^{1 / I n c r e m e n t ~}=$ variable in $\mathrm{Zn}$ rate $6.37 \mathrm{mg} \mathrm{L}^{-1}-$ variable in $\mathrm{Zn}$ rate $0 \mathrm{mg} \mathrm{L}^{-1}$ $\mathrm{mg} \mathrm{kg}^{-1} ;{ }^{2 / E f f i c i e n c y}(\%)=\left\{\left[\left(\right.\right.\right.$ variable in $\mathrm{Zn}$ rate $\left.6.37 \mathrm{mg} \mathrm{L}^{-1} \mathrm{x} 100\right) /($ variable in $\mathrm{Zn}$ rate $\left.\left.\left.0 \mathrm{mg} \mathrm{L}^{-1}\right)\right]-100\right\} ;{ }^{*}$ value found with rate $2.73 \mathrm{mg} \mathrm{L}^{-1}$
The mineral composition results for soybean grains on a dry basis are shown in Table 3 . The $\mathrm{Zn}$ rates did not affect the accumulation of other nutrients in the soybean grains, indicating that there was no micronutrient transport competition between the leaves and the grains when there was a foliar $\mathrm{Zn}$ application at the R4 growth stage. However, there were significant differences between the varieties. The $\mathrm{Ca}, \mathrm{Mg}$, and $\mathrm{P}$ macronutrient levels were highest in BRSMG 800A (3422.83, 2242.841, and $4011.47 \mathrm{mg} \mathrm{kg}^{-1}$, respectively). The highest $\mathrm{K}$ content was found in BRSMG 790A (13806.49 $\left.\mathrm{mg} \mathrm{kg}^{-1}\right)$, while cultivars BRS 010 and BRS 213 accumulated higher levels of $S$.

Variety BRS 213 had higher levels of the micronutrients $\mathrm{B}, \mathrm{Cu}, \mathrm{Fe}$, and $\mathrm{Mn}$, whereas the Mo levels were greatest in BRS 010. Increasing the $\mathrm{Zn}$ application rate did not affect Fe content, which is also an important biofortification nutrient, although it has an antagonistic absorption and transport relationship with $\mathrm{Zn}$ in plants. According to Moosavi and Ronagh (2001), foliar application of nutrients that have antagonistic relationships, is an effective and economical option that avoids yield loss and nutritional imbalances in Fe-efficient soybean plants grown in limestone soils.

The success of agronomic biofortification depends on being able to synchronize the $\mathrm{Zn}$ foliar

Table 3 - Average results of lipid content and mineral composition of the grains of food-type soybean cultivars. Lavras - MG, Brazil, 2014/2015

\begin{tabular}{lrrrrrr}
\hline & BRS 010 & BRS 213 & BRSMG 790A & BRSMG 800A & BRS Favorita RR ${ }^{\circledR}$ & CV $(\%)$ \\
\cline { 2 - 8 } & & \multicolumn{7}{c}{ Lipid $(\% \mathrm{DM})$} \\
\hline $\mathrm{Ca}$ & $20.10 \mathrm{a}$ & $18.89 \mathrm{~b}$ & \multicolumn{1}{c}{$18.83 \mathrm{~b}$} & $19.32 \mathrm{~b}$ & $19.08 \mathrm{~b}$ & 5.51 \\
$\mathrm{~K}$ & $2491.05 \mathrm{c}$ & $2720.05 \mathrm{~b}$ & $1967.60 \mathrm{e}$ & $3422.83 \mathrm{a}$ & $2211.51 \mathrm{~d}$ & 5.70 \\
$\mathrm{Mg}$ & $7867.30 \mathrm{~b}$ & $8357.88 \mathrm{~b}$ & $13806.49 \mathrm{a}$ & $8692.09 \mathrm{~b}$ & $6981.92 \mathrm{c}$ & 14.43 \\
$\mathrm{P}$ & $1869.63 \mathrm{c}$ & $1986.09 \mathrm{~b}$ & $1622.96 \mathrm{~d}$ & $2242.84 \mathrm{a}$ & $1637.36 \mathrm{~d}$ & 3.14 \\
$\mathrm{~S}$ & $3.354 .21 \mathrm{c}$ & $3.521 .00 \mathrm{~b}$ & $3.457 .99 \mathrm{~b}$ & $4.011 .47 \mathrm{a}$ & $3.222 .51 \mathrm{~d}$ & 2.65 \\
$\mathrm{~B}$ & $2.148 .52 \mathrm{a}$ & $2.180 .39 \mathrm{a}$ & $1.820 .25 \mathrm{c}$ & $1.918 .47 \mathrm{~b}$ & $1.678 .29 \mathrm{~d}$ & 3.81 \\
$\mathrm{Cu}$ & $4.54 \mathrm{~b}$ & $6.49 \mathrm{a}$ & $4.60 \mathrm{~b}$ & $3.37 \mathrm{c}$ & $2.70 \mathrm{~d}$ & 10.20 \\
$\mathrm{Fe}$ & $4.00 \mathrm{a}$ & $4.22 \mathrm{a}$ & $3.50 \mathrm{~b}$ & $4.07 \mathrm{a}$ & $3.97 \mathrm{a}$ & 9.03 \\
$\mathrm{Mn}$ & $64.23 \mathrm{~b}$ & $67.34 \mathrm{a}$ & $59.70 \mathrm{c}$ & $61.16 \mathrm{c}$ & $57.99 \mathrm{c}$ & 5.84 \\
$\mathrm{Zn}$ & $44.39 \mathrm{~b}$ & $50.65 \mathrm{a}$ & $34.48 \mathrm{c}$ & $41.20 \mathrm{~b}$ & $34.65 \mathrm{c}$ & 10.67 \\
$\mathrm{Mo}$ & $36.64 \mathrm{~d}$ & $43.91 \mathrm{c}$ & $48.44 \mathrm{~b}$ & $51.59 \mathrm{a}$ & $44.35 \mathrm{c}$ & 3.08 \\
\hline
\end{tabular}

${ }^{1}$ Means followed by the same lower case letter in the line are from the same group according to Scott-Knott test $(p<0.05)$. 
application with other agronomic interventions. Previous research has shown that there is no antagonistic effect between insecticides and $\mathrm{Zn}$ when they are applied simultaneously, indicating that production and $\mathrm{Zn}$ concentration in the grains can both be improved simultaneously (Wang et al., 2015).

To effectively improve the human nutritional status, it is essential that the nutrients in biofortified staple foods are bioavailable (Trijatmiko et al., 2016). Foliar Zn applications improve the Zn bioavailability compared to a soil Zn application. This indicates that it is more economically viable biofortification method that can efficiently improve global health problems (Cakmak, 2008). However, it is necessary to monitor the use of these techniques, using technical and legal methods, to ensure that the micronutrient is available and is consumed by the population; therefore, constant monitoring of intervention programs is required (Vellozo and Fisberg, 2010).

\section{CONCLUSION}

Foliar fertilization with Zn increased plant height, grain mass, and protein content in soybean grains. The foliar application of $6.37 \mathrm{mg} \mathrm{L}^{-1}$ at the R4 stage increased $\mathrm{Zn}$ concentrations in soybean grains. The food-type BRSMG 790A variety had the highest $\mathrm{Zn}$ grain content after a foliar $\mathrm{Zn}$ application. The composition of other minerals in the grains was not affected when foliar $\mathrm{Zn}$ was applied. These results indicate that $Z n$ foliar applications lead to improvements in the $\mathrm{Zn}$ content of edible plant parts, especially when the soil Zn contents are low.

\section{ACKNOWLEDGEMENTS}

To CNPq (Conselho Nacional de Desenvolvimento Científico e Tecnológico) and CAPES (Coordenação de Aperfeiçoamento de Pessoal de Nível Superior) for the scholarship and financial support.

\section{REFERENCES}

Alloway, B.J. (2009) - Soil factors associated with zinc deficiency in crops and humans. Environmental Geochemistry and Health, vol. 31, n. 5, p. 537-542. http://dx.doi.org/10.1007/s10653-009-9255-4

AOAC (2006) - Official methods of analysis. 18th ed. Arlington, Virginia. Association of Official Analytical Chemists.

Bonato, E. R. (2000) - Estresse em soja. 1st ed. Passo Fundo, Embrapa Trigo.

Boonchuay, P.; Cakmak, I.; Rerkasem, B. \& Prom-U-Thai, C. (2013) - Effect of different foliar zinc application at different growth stages on seed zinc concentration and its impact on seedling vigor in rice. Journal Soil Science and Plant Nutrition, vol. 59, n. 2, p. 180-188. http://dx.doi.org/10.1080/00380768.2013.763382

Brunini, M.A.; Barros, M.A.L.; Pereira, M.; Cerqueira, J.B.; Menezes, P.T.R. \& Furtado, I.R. (2016) - Grain quality of eleven soybean cultivars. Nucleus Animalium, vol. 8, p. 55-62.

Cakmak, I. (2008) - Enrichment of cereals grains with zinc: Agronomic or genetic biofortification? Plant and Soil, vol. 302, n. 1-2, p. 1-17. http://dx.doi.org/10.1007/s11104-007-9466-3

Cakmak, I.; Kalayci, M.; Kaya, Y.; Torun, A.A.; Aydin, N.; Wang, Y.; Arisoy, Z. \& Horst, W.J. (2010) Biofortification and localization of zinc in wheat grain. Journal Agriculture and Food Chemistry, vol. 58, n. 16, p. 9092-9102. http://dx.doi.org/10.1021/jf101197h

Ciabotti, S.; Silva, A.C.B.B.; Juhasz, A.C.P.; Mendonça, C.D.; Tavano, O.L.; Mandarino, J.M.G. \& Gonçalves, C.A.A. (2016) - Chemical composition, protein profile, and isoflavones content in soybean genotypes with different seed coat colors. International Food Research Journal, vol. 23, p. 621-629.

Esteves, E.A.; Martino, H.S.D.; Oliveira, F.C.E.; Bressan, J. \& Costa, N.M.B. (2010) - Chemical composition of a soybean cultivar lacking lipoxygenases (LOX2 and LOX3). Food Chemistry, vol. 122, n. 1, p. $238-242$. https://doi.org/10.1016/j.foodchem.2010.02.069

FAO (2015) - The State of Food Insecurity in the World 2015. Meeting the 2015 international hunger targets: taking stock of uneven progress. International Food Policy Research Institute. Rome, FAO.

Gandhi, A.P. (2009) - Quality of soybean and its food products. International Food Research Journal, vol. 16, p. 11-19. 
Gonçalves, L.C.; Andrade, A.P.C.; Ribeiro, G.P. \& Seibel, N.F. (2014)-Chemical composition and technological properties of two soybean cultivars. Biochemistry and Biotechnology Reports, vol. 3, n. 1, p. 33-40. https://doi. org/10.5433/2316-5200.2014v3n1p33

Joy, E.J.M.; Alexander, J.S.; Young, S.D.; Ander, E.L.; Watts, M.J. \& Broadley, M.R. (2015) - Zinc-enriched fertilisers as a potential public health intervention in Africa. Plant and Soil, vol. 389, n. 1-2, p. 1-24. https:// doi.org/10.1007/s11104-015-2430-8

Keatinge, J.D.H.; Easdown, W.J.; Yang, R.Y.; Chadha, M.L. \& Shanmugasundaram, S. (2011) - Overcoming chronic malnutrition in a future warming world: the key importance of mung bean and vegetable soybean. Euphytica, vol.180, n. 1, p. 129-141. https://doi.org/10.1007/s10681-011-0401-6

Lyi, S.M.; Heller, L.I.; Rutzke, M.; Welch, R.M.; Kochian, L.V. \& Li, L. (2005) - Molecular and biochemical characterization of the selenocysteine Se-methyltransferase gene and Semethylselenocysteine synthesis in broccoli. Plant Physiology, vol. 138, p. 409-420. https://doi.org/10.1104/pp.104.056549

Mao, H.; Wang, J.; Wang, Z.; Zan, Y.; Lyons, G. \& Zou, C. (2014) - Using agronomic biofortification to boost zinc, selenium, and iodine concentrations of food crops grown on the loess plateau in China. Journal of Soil Science and Plant Nutrition. vol. 14, n. 2, p. 459-470.

Moosavi, A.A. \& Ronaghi, A. (2011) - Influence of foliar and soil applications of iron and manganese on soybean dry matter yield and iron-manganese relationship in a Calcareous soil. Australian Journal of Crop Science, vol. 5, p. 1550-1556.

Moraes, R.M.A.; José, I.C.; Ramos, F.G.; Barros, E.G. \& Moreira, M.A. (2006) - Biochemical characterization of soybean lines with high protein content. Pesquisa Agropecuária Brasileira, vol. 41, n. 5, p. 725-729. http:// dx.doi.org/10.1590/S0100-204X2006000500002

Rigo, A.A.; Dahmer, A.M.; Steffens, C. \& Steffens, J. (2015) - Characterization of Soybean Cultivars Genetically Improved for Human Consumption. International Journal of Food Engineering, vol. 1, n. 1, p. 1-7. http://dx.doi. org/10.18178/ijfe.1.1.1-7

Sharma, A.; Patni, B.; Shankhdhar, D. \& Shankhdhar, S.C. (2013) - Zinc-An Indispensable Micronutrient. Physiology and Molecular Biology of Plants, vol. 19, n. 1, p. 11-20. http://dx.doi.org/10.1007/s12298-012-0139-1

Trijatmiko, K.R.; Dueñas, C.; Tsakirpaloglou, N.; Torrizo, L.; Arines, F.M.; Adeva, C. \& Slamet-Loedin, I.H. (2016) - Biofortified indica rice attains iron and zinc nutrition dietary targets in the field. Scientific Reports, vol. 6, art. 19792. http://dx.doi.org/10.1038/srep19792

Vellozo, E.P. \& Fisberg, M. (2010) - O impacto da fortificação de alimentos na prevenção da deficiência de ferro. Revista Brasileira de Hematologia, vol. 32, sup. 2, p. 134-139. http://dx.doi.org/10.1590/S1516-84842010005000069

Wang, X.Z.; Liu, D.Y.; Zhang, W.; Wang, C.J.; Cakmak, I. \& Zou, C.Q. (2015) - An effective strategy to improve grain zinc concentration of winter wheat, Aphids prevention and farmers' income. Field Crops Research, vol. 184, p. 74-79. https://doi.org/10.1016/j.fcr.2015.08.015

White, P.J. \& Broadley M.R. (2009) - Biofortification of crops with seven mineral elements often lacking in human diets - iron, zinc, copper, calcium, magnesium, selenium and iodine. New Phytologist. vol. 182, n. 1, p. 49-84. https://doi.org/10.1111/j.1469-8137.2008.02738.x

Zhao, A.; Lu, X.; Chen, Z.; Tian, X. \& Yang, X. (2011) - Zinc Fertilization Methods on Zinc Absorption and Translocation in Wheat. Journal of Agricultural Science, vol. 3, n. 1, p. 28-35. http://dx.doi.org/10.5539/jas.v3n1p28 